\title{
Komparasi Algoritma Machine Learning dan Deep Learning untuk Named Entity Recognition : Studi Kasus Data Kebencanaan
}

Nuli Giarsyani*, Ridho Rahmadi, Ahmad Fathan Hidayatullah

Program Studi Informatika Program Magister, Fakultas Teknologi Industri, Universitas Islam Indonesia

*Email: nuli.giarsyani@students.uii.ac.id

\begin{tabular}{|c|c|}
\hline Info Artikel & Abstrak \\
\hline $\begin{array}{l}\text { Kata Kunci : } \\
\text { named entity recognition, disaster, } \\
\text { machine learning, deep learning } \\
\text { Keywords: } \\
\text { named entity recognition, disaster, } \\
\text { machine learning, deep learning } \\
\text { Tanggal Artikel } \\
\text { Dikirim : } 24 \text { April } 2020 \\
\text { Direvisi : } 20 \text { Mei } 2020 \\
\text { Diterima : } 25 \text { Mei } 2020\end{array}$ & 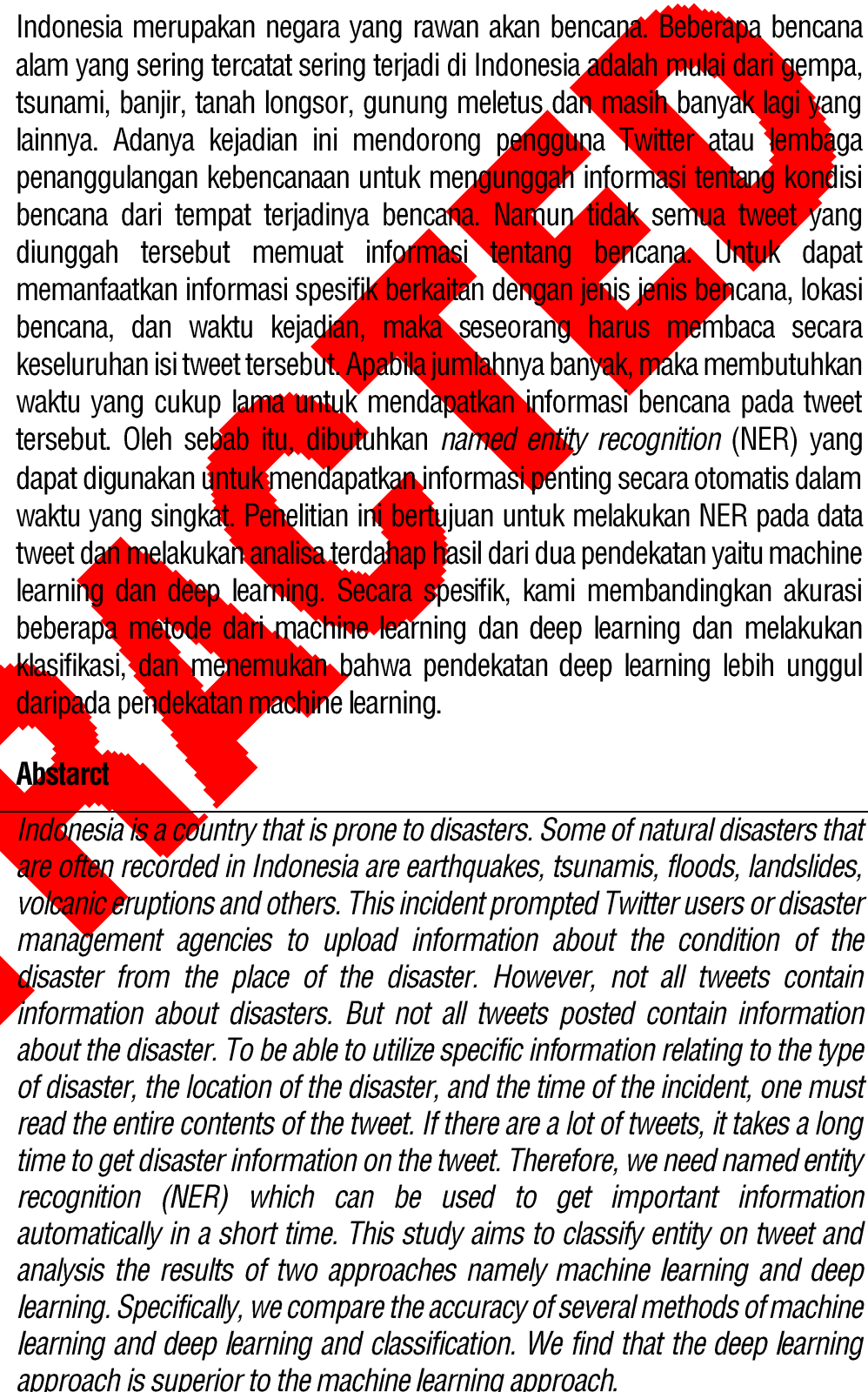 \\
\hline
\end{tabular}




\section{PENDAHULUAN}

Saat ini media sosial telah menjadi bagian penting dari kehidupan seseorang. Berbagai kalangan, usia, dan hampir semua lapisan masyarakat Indonesia telah memiliki dan menggunakan media sosial sebagai salah satu sarana guna memperoleh dan menyampaikan informasi kepada publik [1]. Pada prakteknya, media sosial sering mengambil peran media tradisional dalam melaporkan peristiwa atau kejadian terkini [2], seperti bencana alam, di mana laporan atau informasi yang hadir bisa lebih cepat dan berasal langsung dari lokasi bencana [3]. Oleh sebab itu, media sosial banyak dimanfaatkan oleh organisasi atau lembaga yang bergerak pada bidang penanggulangan bencana untuk memberikan informasi terkait bencana.

Salah satu media sosial yang dimanfaatkan dalam melaporkan informasi bencana alam adalah Twitter. Dalam beberapa tahun terakhir, Twitter telah menjadi saluran utama untuk komunikasi selama bencana alam [4]. Hal tersebut dikarenakan Twitter merupakan salah satu media jejaring sosial dengan pengguna terbanyak diantara beberapa situs jejaring sosial yang ada [5]. Data menunjukkan bahwa Twitter memiliki sekitar 288 juta pengguna aktif, memposting lebih dari 500 juta tweet per hari dan memiliki jaringan yang paling cepat berkembang [6]. Sedangkan untuk di negara Indonesia sendiri jumlah pengguna Twitter menempati peringkat ke 5 , terbesar di dunia.

Indonesia merupakan negara yang rawan akan bencana. Beberapa bencana alam yang sering terjadi di Indónesią mulai dari gempa, tsunami, banjir, tanah longsor, gunung meletus dan masih banyak lagi yang lainnya. Adanya kejadian ini mendorong pengguna Twitter atau lembaga penanggulangan kebencanaan untuk mengunggah informasi tentang kondisi bencana daritempat terjadinya bencana. Namun tidak semua tweet yang diunggah tersebut memuat informasi tentang bencana. Untuk dapat memanfaatkan informasi tersebut seperti mendapatkan informasi jenis bencana, lokasi bencana, dan waktu kejadian, maka seseorang harus membaca secara keseluruhan isi tweet tersebut. Apabila jumlahnya banyak, maka seseorang akan membutuhkan waktu yang cukup lama untuk mendapatkan informasi bencana pada tweet tersebut. Oleh sebab itu, dibutuhkan named entity recognition(NER) yang dapat digunakan untuk mendapatkan informasi penting secara otomatis dari tweet-twweet tersebut dalam waktu yang relatif singkat.

Named entity recognition adalah proses otomatis mengekstraksi entitas bernama yang dianggap penting di dalam sebuah teks dan menentukan kategorinya ke dalam kategori terdefinisi [7]. Sebagai contoh dalam tweet informasi bencana, NER dapat mengekstraksi jenis bencana, lokasi bencana, dan waktu kejadian. NER pada tweet infokmasi bencana biasanya dibutuhkan oleh pihak tertentu untuk mengidentifikasi bencana, dan memantau keadaan ketika terjadi bencaná.

Penelitian ini bertujuan untuk melakukan named entity recognitiongunà mengíidentifikasi dan mengklasifikasikan kata pada tweet yang memuat informasi bencana ke dalam entitas-entitas yang telah ditentukan. Selain itu, penelitian ini juga akan memberikan kontribusi terhadap NER pada domain kebencanaan dalam bahasa Indonésia, karena NER pada domain tersebut masih sangat terbatas. NER pada domain kebencanaan ini merupakan langkah awal untuk topik penelitian terkait information extraction, question answering system, dan sistem monitoring keb

Pendekatan yang digunakan dalam penelitian ini adalah máchine learning dan deep learning. Algoritma machine learning yang digunakan pada penelitian adalah naive bayes, support vector machines, decision tree, dan random forest. Sedangkan algoritma deep learningyang digunakan adalah/ong shortterm memory (LSTM), convolutional neural network (CNN), dan gated recurrent units (GRU). Pendekatan dengan berbagai macam metode ini bertujuan untuk memberikan gambaran secara komprehensif terhadap performa masing-masing metode yang harapannya dapat dijadikan landasan saintifik bagi kasus-kasus yang serupa.

2. METODE.PENELITIAN

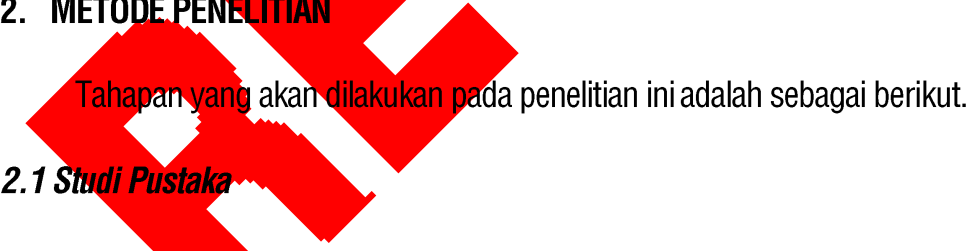

Studi pustaka dilakukan untuk mengkaji dan mempelajari sumber literatur dan teori-teori yang berhubungan atau berkaitan dengan penelitian yang sedang dilakukan. Landasan yang diambil atau digunakan dalam studi literatur ini bersumber dari penelitian ilmiah, buku, artikel, jurnal, dan sumber pembelajaran lainnya.

\subsection{Persiapan Data}

Data yang digunakan pada penelitian ini bersumber dari Twitter. Data tersebut merupakan data mentah dari tweettweet yang berisi informasi tentang bencana di Indonesia. Jumlah data yang dikumpulkan sebanyak 378.602 tweet. Data tersebut diambil dari akun Twitter BMKG (Badan Meteorologi, Klimatologi, dan Geofisika) dan BNPB (Badan Nasional Penanggulangan Bencana) baik yang berada di pemerintah pusat sampai dengan pemerintah daerah. 
Data tweet diambil dengan menggunakan library tweepy dalam bahasa python. Proses pengumpulan data menggunakan tweepy dimulai dari melakukan proses autentikasi ke Twitter dengan menggunakan method atau function yang telah disediakan oleh tweepy. Proses autentikasi membutuhkan beberapa data diantaranya consumer key, consumer secret, access token, dan access token secret. Data untuk proses autentikasi diperoleh dari layanan Twitter Developer. Layanan tersebut disediakan oleh Twitter agar pengguna bisa menggunakan fitur-fitur yang ada pada Twitter.

Setelah melalui proses autentikasi, selanjutnya akan dilakukan proses pengambilan data tweet dengan memanfaatkan methodatau function pada library tweepy. Kemudian data tweet tersebut dikumpulkan menjadi satu kedalam satu dokumen.

Pada penelitian ini, data tweet akan dibagi menjadi dua bagian yaitu data training dan data testing. Data training nantinya akan digunakan untuk melatih dengan menggunakan beberapa algoritma klasifikasi dalam machine learning maupun deep learning sehingga menghasilkan sebuah model. Data testing akan digunakan untuk mengetes performa dari model yang telah dibuat.

\subsection{Komputasi Model}

Komputasi model yang akan dilakukan dalam penelitian ini terbagi menjadi beberapa bagian diantaranya pra pemrosesan, part of speech tagging, entity tagging, feature extraction, pembagian data set, dan training model seperti ditunjukkan gambar 1.

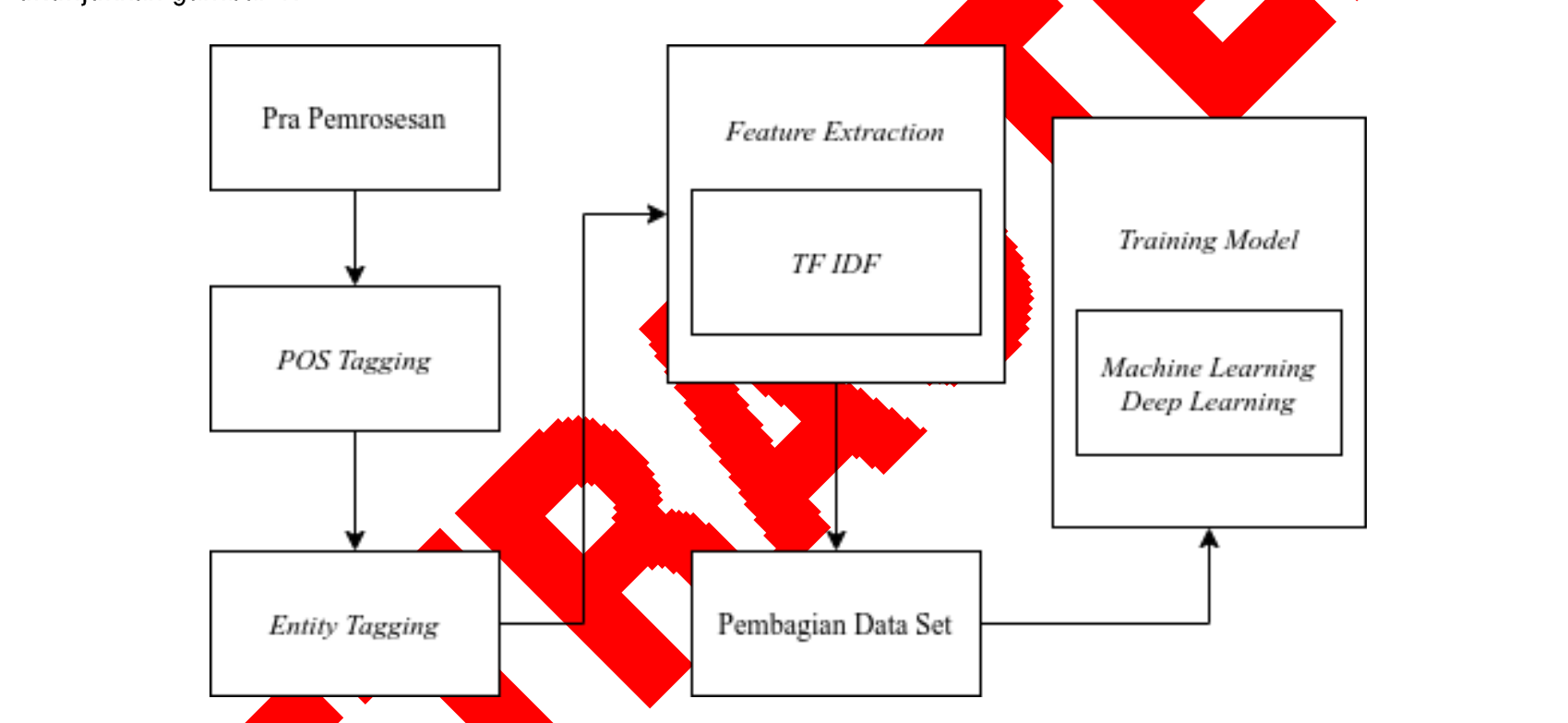

2.4 Evaluasi

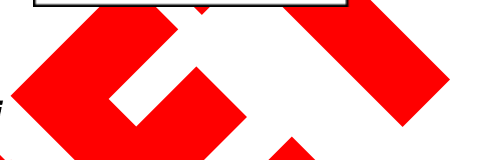

Gambar 1. Komputasi Model

Evaluasi terhadap model yang telah dibangun dari proses training merupakan hal yang sangat penting. Tujuan evaluasi adălah untuk mengukur apakah model mampu melakukan klasifikasi dengan baik atau tidak. Hasil dari proses evaluasi ini digunakan untuk mengetahui kinerja dari model. Sehingga memperoleh mana model terbaik yang dihasilkan dari setiap algoritma yâng telab disebutkan di atas. Metode evaluasi yang digunakan pada penelitian ini adalah perbandingan akurasi. Akurasi sebuahalgoritma mengindikasikan persentase dari prediksi yang benar. Formula dari akurasi adalah

$$
\text { Akurasi }=\frac{\text { Jumlah Prediksi Benar }}{\text { Jumlah Total Prediksi }}
$$

atau lebih detailnya,

$$
\text { Akurasi }=\frac{P B+N B}{P B+N B+P P+N P}
$$

di mana $P B=$ Positif Benar, $N B=$ Negatif Benar, $P P=$ Positif Palsu, dan $N P=$ Negatif Palsu. 
Keterangan :

$P B$ : Jumlah data positif yang terklasifikasi dengan benar.

$N B$ : Jumlah data negatif yang terklasifikasi dengan benar.

$P P$ : Jumlah data negatif namun terklasifikasi sebagai data positif.

$N P$ : Jumlah data positif namun terklasifikasi sebagai data negatif.

\section{HASIL DAN PEMBAHASAN}

Hasil penelitian named entity recognition ini berfokus pada analisis dari variasi ukuran sampel data set terhadap kinerja algoritma machine learning dan deep learning. Analisis performa kinerja dari algoritma diperoleh berdasarkan akurasi.

\subsection{Hasil Akurasi}

Hasil akurasi dibagi menjadi dua bagian, yaitu akurasi pada rasio 70\%-30\% dan akurasi pada rasio $80 \%-20 \%$. Setiap algoritma pada kedua rasio menggunakan sample size yang berbeda-beda. Sample size yang digunakan mulaildari $50 \%, 60 \%, 70 \%, 80 \%, 90 \%$ dan $100 \%$ dari data tweet yang berjumlah 378.602 .

1. Rasio $70 \%-30 \%$

Tabel 1. Akurasi Rasio 70\%-30\%

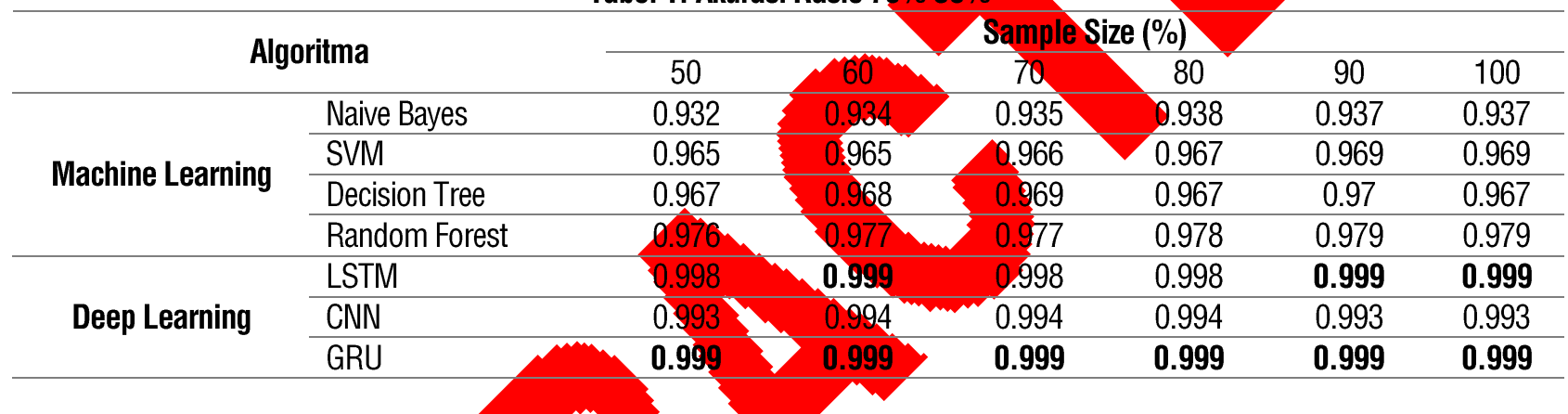

Berdasarkan dari hasil akurasi yang ditampilkan pada Tảbel 1 di atas dapat disimpulkan bahwa pada sample size $50 \%$ akurasi terbaik dihasilkan oleh algoritma GRU sebesar 0.999, pada sample size 60\% akurasi terbaik dihasilkan oleh algoritma LSTM dan GRU sebesar 0.999 , pada sample size $70 \%$ dan $80 \%$ akurasi terbaik dihásilkan oleh algoritma GRU, pada sample size $90 \%$ dan $100 \%$ akurasi terbaik dihasilkan oleh algoritma LSTM dan GRU. Setiap algoritma pada setiap sample size memiliki selisih yang berbeda- beda, seperti pada sample size $50 \%$ rentang perbedaan akurasinya ada diantara $0.001-0.067$, pada sample size $60 \%$ selisihnya antara $0.005-0.065$, pada sample size $70 \%$ antara $0.001-0.064$, pada sample size $80 \%$ antara $0.001-0.061$, pada sample size $90 \%$ dan $100 \%$ berada diantara 0.006-0.062.

Selain dilihat berdasarkan sample size, juga dapat disimpulkan berdasarkan algoritma, seperti pada algoritma naive bayes mendapatkanakurasi terbaik dengan nilai 0.938 pada sample size $80 \%$, dan akurasi terburuk dengan nilai 0.932 pada sample size $50 \%$. Algoritma SVM memperoleh akurasi terbaik pada sample size $90 \%$ dan 100\% dengan nilai 0.969 . Algoritma Decision Treememperoleh hasil akurasi tèrbaik sebesar 0.97 pada sample size $90 \%$. Algoritma random forestmemperoleh hasil akurasi terbaik pada sample size $90 \%$ dan $100 \%$ denga nilai 0.979 . Algoritma LSTM memperoleh akurasi terbaik dengan nilai 0.999 pada sample size $60 \%, 90 \%$ dan $100 \%$. Algoritma CNN memperoleh akurasi terbaik dengan nilai 0.994 pada sample size $60 \%, 70 \%$ dan $80 \%$. Algoritma GRU memperoleh akurasi terbaik dengan nilai 0.999 pada semua sample size.

Pada Gambar 2 dapat dilihat secara keseluruhan bahwa pendekatan deep learning menunjukkan nilai akurasi lebih tinggi dibandingkan dengan pendekatan machine learning. Pada pendekatan machine learning, nilai akurasi tertinggi dihasilkan oleh algoritma random forest dan terburuk dihasilkan oleh algoritma naive bayes. Sedangkan pada pendekatan deep learning, nilai akurasi tertinggi dihasilkan oleh algoritma GRU dan nilai akurasi terburuk dihasilkan oleh algoritma CNN. 
IJAI (Indonesian Journal of Applied Informatics)

Vol. 4 No.2 Tahun 2020 pISSN: 2548-3846, elSSN: 2598-5981

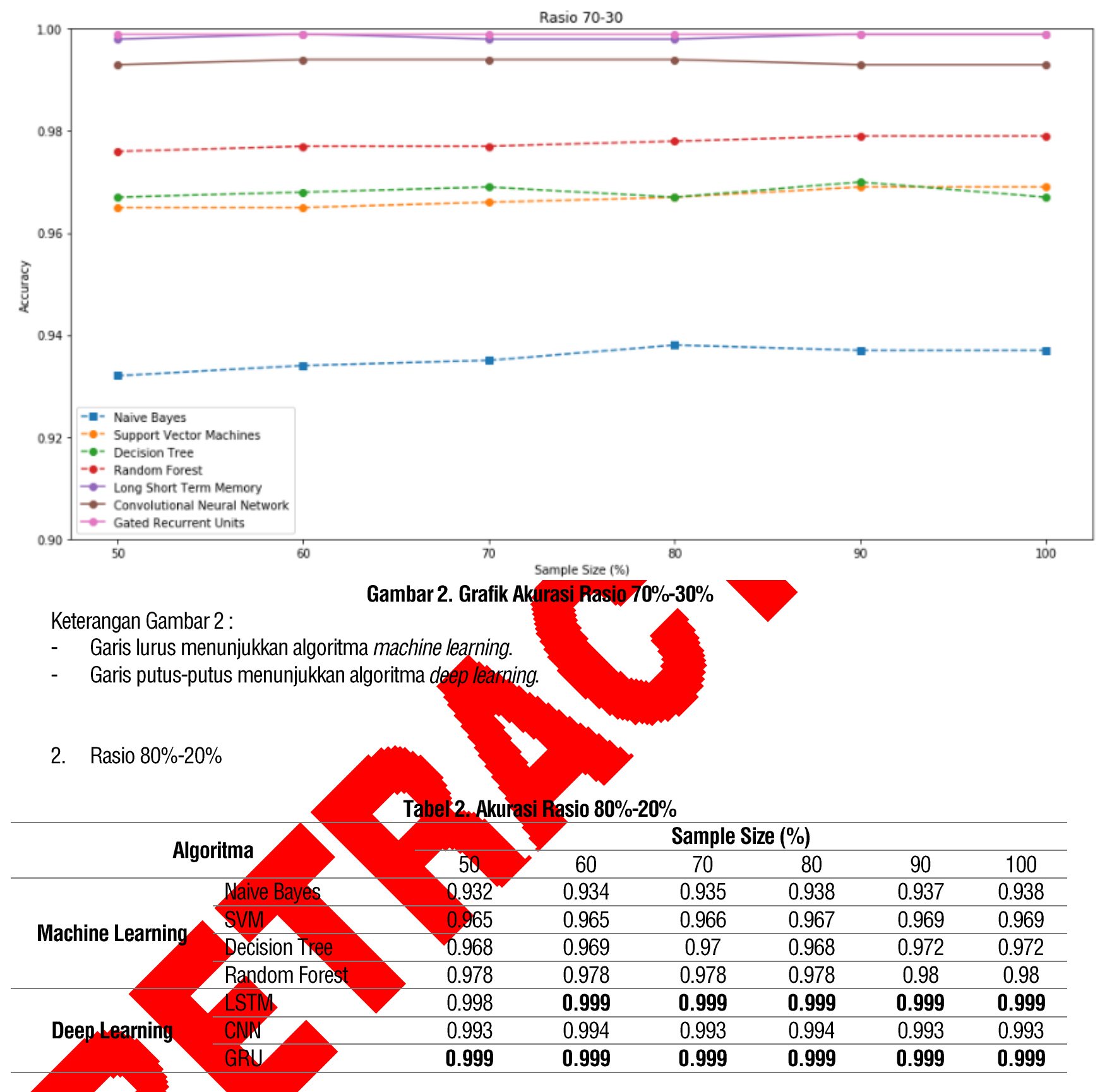

Berdasarkan dari hasil akurasi yang ditampilkan pada Tabel 2 di atas dapat disimpulkan bahwa pada sample size $50 \%$ akurasi terbaik dihasilkan oleh algoritma GRU sebesar 0.999, pada sample size 60\% sampai dengan 100\% akurasi terbaik dihasilkan oleh algoritma LSTM dan GRUdengan nilai 0.999 .

Setiap sample size memiliki selisih yang berbeda-beda, seperti pada sample size $50 \%$, rentang perbedaan akurasi setiap algoritmanya ada diantara 0.001-0.067, pada sample size $60 \%$ selisihnya antara $0.005-0.065$, pada sample size $70 \%$ antara 0.006 0.064, pada sample size $80 \%$ antara 0.005-0.061, pada sample size $90 \%$ antara $0.005-0.062$ dan $100 \%$ berada diantara $0.005-0.061$.

Selain dilihat berdasarkan sample size, juga dapat dilihat berdasarkan algoritma, seperti pada algoritma naive bayes mendapatkan akurasi terbaik dengan nilai 0.938 pada sample size $100 \%$, dan akurasi terburuk dengan nilai 0.932 pada sample size $50 \%$. Algoritma SVM memperoleh akurasi terbaik pada sample size $90 \%$ dan $100 \%$ dengan nilai 0.969 . Algoritma Decision Tree memperoleh hasil akurasi terbaik sebesar 0.972 pada sample size $90 \%$ dan $100 \%$. Algoritma random forestmemperoleh hasil akurasi terbaik pada sample size $90 \%$ dan $100 \%$ denga nilai 0.98 . Algoritma LSTM memperoleh akurasi terbaik dengan nilai 0.999 pada sample size $60 \%$, sampai $100 \%$. Algoritma CNN memperoleh akurasi terbaik dengan nilai 0.994 pada sample size $60 \%$ dan $80 \%$. Algoritma GRU memperoleh akurasi terbaik dengan nilai 0.999 pada semua sample size. 
Pada Gambar 3 dapat dilihat secara keseluruhan bahwa pendekatan deep learning menunjukkan nilai akurasi lebih tinggi dibandingkan dengan pendekatan machine learning. Pada pendekatan machine learning, nilai akurasi tertinggi dihasilkan oleh algoritma random forest dan terburuk dihasilkan oleh algoritma naive bayes. Sedangkan pada pendekatan deep learning, nilai akurasi tertinggi dihasilkan oleh algoritma GRU dan nilai akurasi terburuk dihasilkan oleh algoritma CNN.

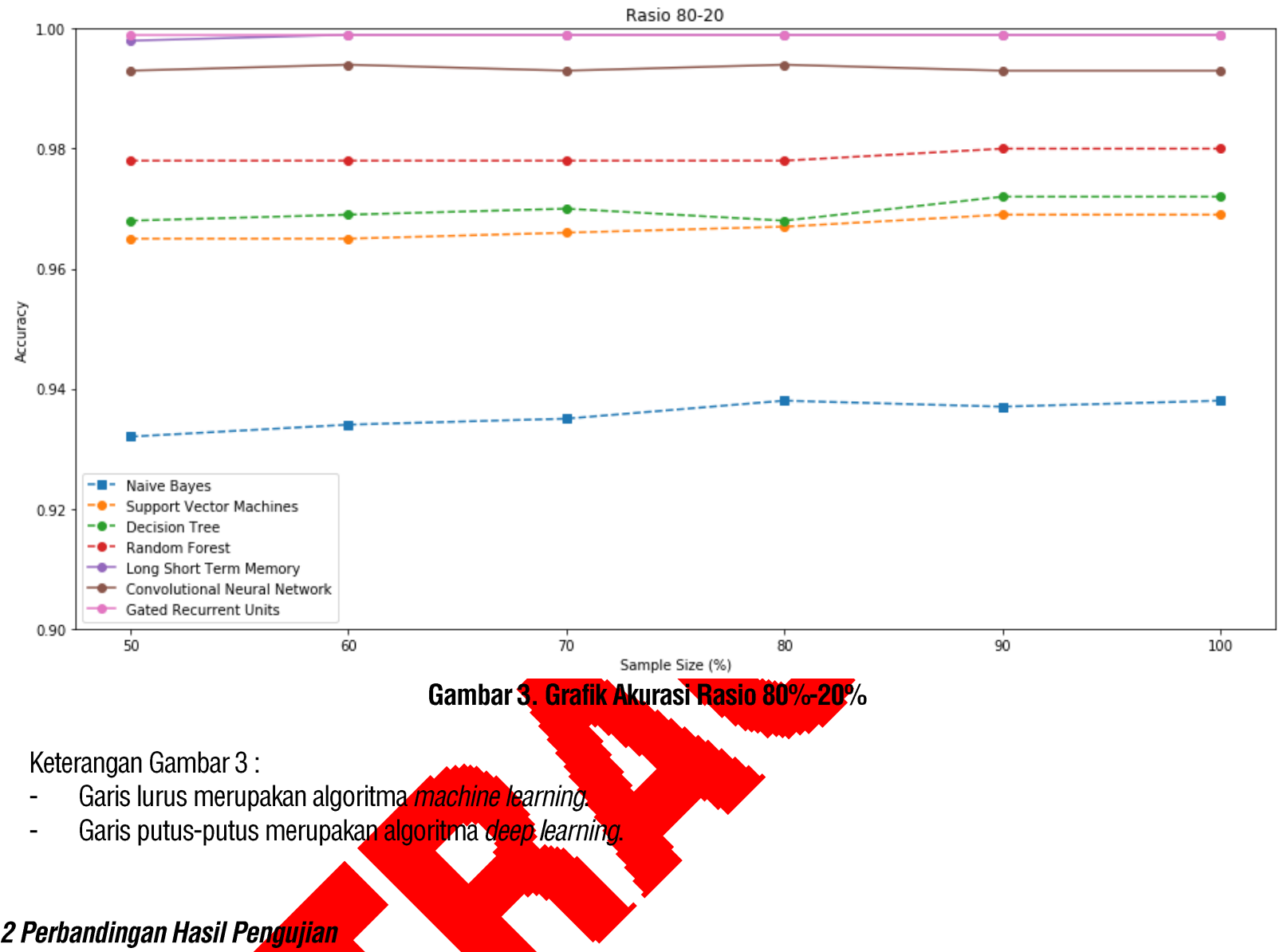

Hasil komputasi menggunakan algoritma machine learning dan deep learning dengan rasio 70-30 dan 80-20 pada Tabel 3.1 dan Tabel 3.2 menghasilkan beberapa perbedaan akurasi, djantara :

1. Hasil akurasi menggunakan algoritma decision tree pada rasio $80-20$ untuk sample size $50 \%, 60 \%, 70 \%$ dan $80 \%$ sedikit lebih baik daripada rasio 70-30, selisih antara keduanya adalah sebesar 0.001 . Pada sample size $90 \%$ selisihnya sebesar 0.002 dan sample size $100 \%$ sebesar 0.005 .

2. Hasil akurasi algoritma random forest pada rasio $80-20$ untuk sample size $50 \%$ sedikit lebih baik dari rasio $70-30$, dengan perbedaan sebesar 0.002. Sedangkan pada sample size $60 \%, 70 \%, 90 \%$ dan $100 \%$ selisihnya sebesar 0.001 .

Pada algoritma naive bayes terlihat lebih baik pada rasio 80-20 untuk sample size 100\% dengan selisih sebesar 0.001 .

Pada algoritma long short term memory, akurasi yang lebih baik dihasilkan oleh rasio 80-20 untuk sample size $70 \%$ dan $80 \%$ selisih sebésar 0.001 .

5. Pada algoritma convolutional neural network, akurasi yang lebih baik dihasilkan oleh rasio 70-30 pada sample size $70 \%$ dengan selisih sebesar 0.001 .

\section{KESIMPULAN}

Berdasarkan hasil penelitian yang telah dilakukan, maka dapat diambil beberapa kesimpulan yaitu guna mendapatkan model terbaik, dilakukan proses training menggunakan algoritma machine learning dan deep learning. Algoritma machine learning yang digunakan pada penelitian adalah naive bayes, Support vector machines, decision tree, dan random forest. Sedangkan algoritma deep learning yang digunakan adalah long short term memory, convolutional neural network, dan gated recurrent units. Berdasarkan eksperimen, metode deep learning menghasilkan akurasi yang lebih baik daripada metode machine learning dengan akurasi terbaik dihasilkan dari algoritma deep learning yaitu gated recurrent units dan long short term memory sebesar 0.999. Adapun hasil akurasi terbaik pada metode machine learning dihasilkan oleh algoritma random forest dengan akurasi 0.98. Pada proses training, diketahui 
bahwa semakin besar ukuran sample size, maka akurasinya semakin tinggi. Namun selisih akurasi antara sample size terkecil hingga terbesar tidak terlalu jauh dan pada algoritma deep learning menunjukkan bawah ukuran sample size tidak terlalu mempengaruhi akurasi. Akurasi yang dihasilkan oleh algoritma deep learning cenderung stabil, baik pada sample size terkecil maupun sample size terbesar.

\section{DAFTAR PUSTAKA}

[1] A. S. Cahyono, "Pengaruh Media Sosial Terhadap Perubahan Sosial Masyarakat di Indonesia," J. ilmu Sos. dan ilmu Polit., pp. 140-157, 2016.

[2] J. An, M. Cha, K. Gummadi, and J. Crowcroft, "Media landscape in Twitter: A world of new conventions and political diversity," Assoc. Adv. Artificial Intell., pp. 18-25, 2011.

[3] H. Februariyanti, E. Zuliarso, D. Bulan, and L. Suryati, Rancang bangun sistem layanan informasi bencana melalui twitter menggunakan basis data xml, vol. 035, no. November. 2013.

[4] Z. Ashktorab, C. Brown, M. Nandi, and A. Culotta, "Tweedr: Mining Twitter to Inform Disaster Response," Proc. 11th Int. ISCRAM Conf., vol. 12, no. 4, pp. 354- 358, 2014.

[5] A. F. Hidayatullah, "Analisis Sentimen dan Klasifikasi Kategori Terhadap Tokoh Publik Pada Twitter," TESIS, vol. 2014, no. semnasIF, p. A-1, 2014.

[6] L. Derczynski et al., "Analysis of named entity recognition and linking for tweets," Inf. Process. Manag., vol. 51, no. 2, pp. 32-49, 2015.

[7] Y. Wibisono and M. L. Khodra, "Pengenalan Entitas Bernama Otomatis untuk Bahasa Indonesia dengan Pendekatan Pembelajaran Mesin," pp. 1-5, 2018. 